\title{
重錘落下締固め工法における地盤の改良深度および 改良程度に関する検討

\author{
DEPTH AND DEGREE OF SOIL IMPROVEMENT \\ BY DYNAMIC CONSOLIDATION METHOD
}

\author{
下平祐司*, 山肩邦男** \\ Yuuji SHIMOHIRA and Kunio YAMAGATA
}

\begin{abstract}
This paper examines the soil improvement effect $\left(D_{N}, \bar{N}_{2}\right)$ of Dynamic Consolidation Method to sandy ground based on the past construction records. The main conclusions are summarized as follows.

(1) $D_{N}$ is the depth of the improvement required, taken as determined by the intersection of the two approximate curves of $N$-value before and after the improvement. Equations for estimating $D_{N}$ are proposed. (2) Equations for estimating $\bar{N}_{2}$ are proposed, where $\bar{N}_{2}$ is the average of $N$-value after the improvement. (3) Proposed estimate equations are applied to two recently reported construction records, and the propriety of them is discussed.
\end{abstract}

Keywords : soil improvement, tamping, sandy soil, relative density, $N$-value 地盤改良, 締固め, 砂質土, 相対密度, $N$ 值

1. 序

重錘落下締固め工法は, 衝撃力によって地盤を締固め る地盤改良工法の一種であって, 重量数 $10 \mathrm{tf} の$ 重鍾を 数 $10 \mathrm{~m}$ の高さから繰り返し自由落下させるというきわ めて単純な地盤改良工法である。同工法は, はじめ砂や 砂礫などの粗粒土の締固め工法として開発されたもので あるが, 現在では都市廃棄物地盤から岩砕埋め立て地盤 にわたる広範囲な土質に対して適用されている。通常の 場合の施工手順を図一1に示す。本タンピングでは，地 盤の深部を改良するために等間隔においた各地点におい て繰り返し打撃を行う。本タンピングが終了した後, 打 撃孔周辺のゆるんだ浅部を締固めるため, 地表面を均し てべた打ち状に仕上げタンピングが行われる。なお，施 工方法の詳細については，文献1.2)などを参照されたい。 重鍾落下締固め工法の設計法は主に過去の経験に基づ くものであるため, その不備な点を施工途中に実施する サウンディングなどによって補っているのが現状であ

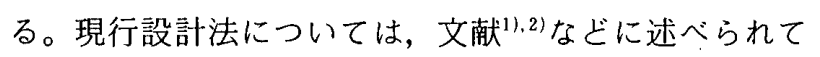
いるが, 改良深度の定義が明確でないことなど問題点も 多く, 設計法としては不十分であると考えられる。また, 高田ら ${ }^{3 \sim \sim 7}$ の遠心模型実験による一連の研究では, 同工
法の締固めに及ぼす各種要因についてパラメトリックな 実験が行われている。これらの結果として, 総打撃エネ ルギーが大きくなるほど地盤の圧縮量が大きくなるこ $亡^{4)}$, 総打撃エネルギー一定のもとでは, 締固的効果は エネルギーよりも重鍾の持つ運動量に強く依存している こどなどが定性的に報告されているが，春地盤を想定 した具体的な提案には至っていない。

以上のような背景のもとで，本研究では，対象地盤を 砂質系地盤に限定して, 重鍾落下締固め工法の設計法に 関する検討を行った。すなわち，同工法の改良効果への 影響要因として地盤の種類（砂地盤および砂磁・岩砕地

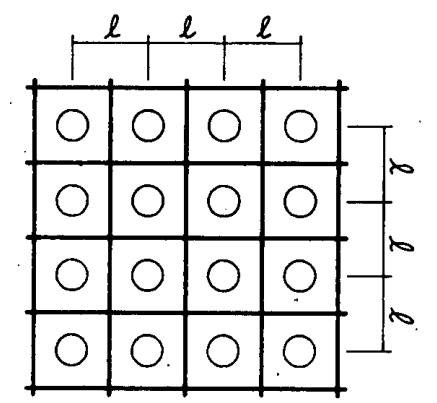

(a) 本タンピング

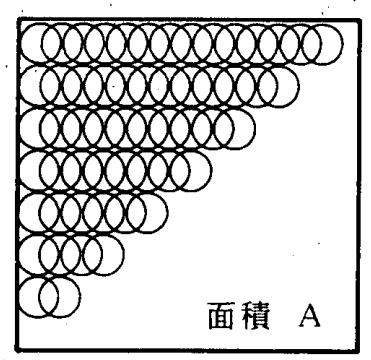

(b) 仕上げタンピンク
図一1重鍾落下締固め工法の施工手順
* 日本建築総合試験所 研究員・修士 (工学)

** 関西大学工学部建築学科 教授. 博士 (工学)
Research Engineering, General Building Research Corporation, M. Eng.

Prof., Dept. of Architecture, Faculty of Engineering, Kansai Univ., Dr. Eng. 
盤), 相対密度 ( $N$ 値), 打撃エネルギーの 3 要因を想 定し，国内における過去の施工記録を対象資料として改 良梁度おょび改良程度について調査検討し，それぞれの 推定式を提案した。

なお，本論文の内容は，文献 8）に中間報告したもの に加筆，修正したものであることをお断りしておく。

\section{2. 現行設計法の問題点および本研究における定義}

現行設計法における改良梁度および改良程度の推定方 法を図一 2 および図一 3 に示す11.2)。図一2 は，改良深度 が重錘の重量 $W$ と落下高さ $H$ との積の平方根に比例 する(比例定数 $\alpha$ : 影響係数”) とするものであるが, 問題点として以下の事項が挙げられる。

(1) 改良梁度 $D$ が明確に定義されていないこと（通常 は, 施工前後の $N$ 值などが変わらない深度を目視によっ て判断しているようである)。

(2) 1 打撃についての打撃エネルギーのみを考虑してい るため, 打撃回数, 打撃点間隔, 打撃エネルギーの総量 が考慮されていないこと。

(3) 改良対象地盤の相対密度が考慮されていないこと。

図一 3 は, 施工前後の平均 $N$ 值の増分 $\Delta \bar{N}$ が単位体 積当たりの打撃エネルギー $E_{v}$ に比例するとするもので あるが, 問題点として次のことが挙げられる。

(4) 単位体積当たりの打撃エネルギー $E_{v}$ (後述 $(5)$ 式の $E_{a}$ を改良梁度 $D$ で除したもの）に(1)で述べたよう に明確な定義のない $D$ が導入されていること。

以上のことから, 本研究では, 以下のことを考虑する こととした。

1）(1および(4)に関しては，改良深度を以下のように定 義する。すなわち，施工前の $N$ 值 $\left(N_{1}\right)$, 施工後の $N$ 值 $\left(N_{2}\right)$ の深度分布をそれぞれ (1) 式の 2 次曲線で 近似し， 2 曲線が交差する梁度を改良深度 $D_{N}$ と定義し た。

$N$ 値 $=a_{z}+b_{z} \cdot z+c_{z} \cdot z^{2}$

ここに, $z:$ 深度 $(\mathrm{m})$

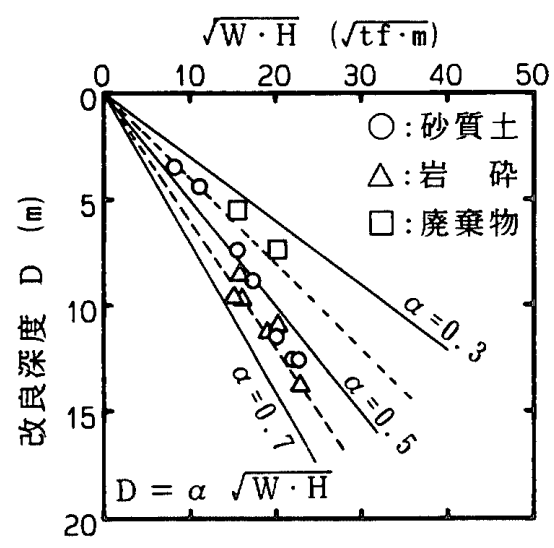

図-2 $\sqrt{W \cdot H} \sim D$ 関係 ${ }^{\prime \prime}$

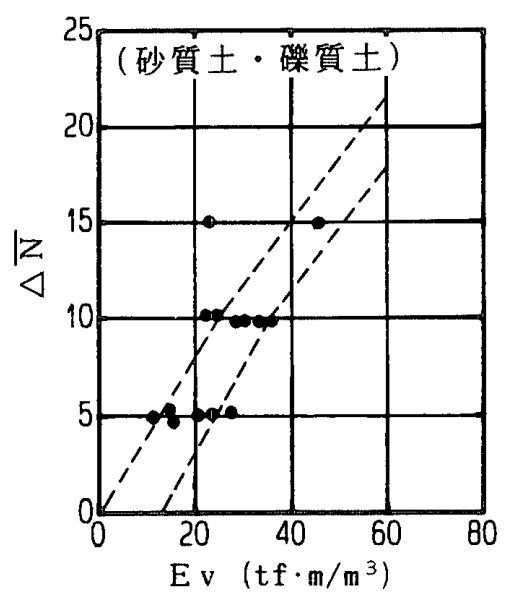

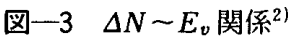

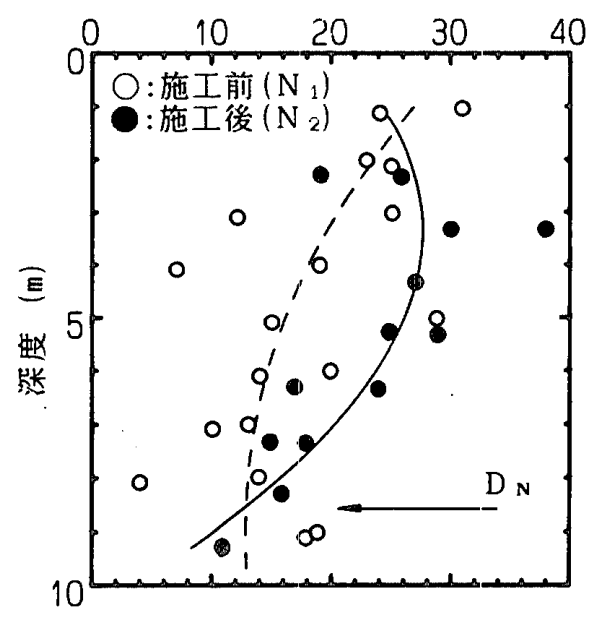

図一4 改良深度 $D_{N}$ 判定の一例 


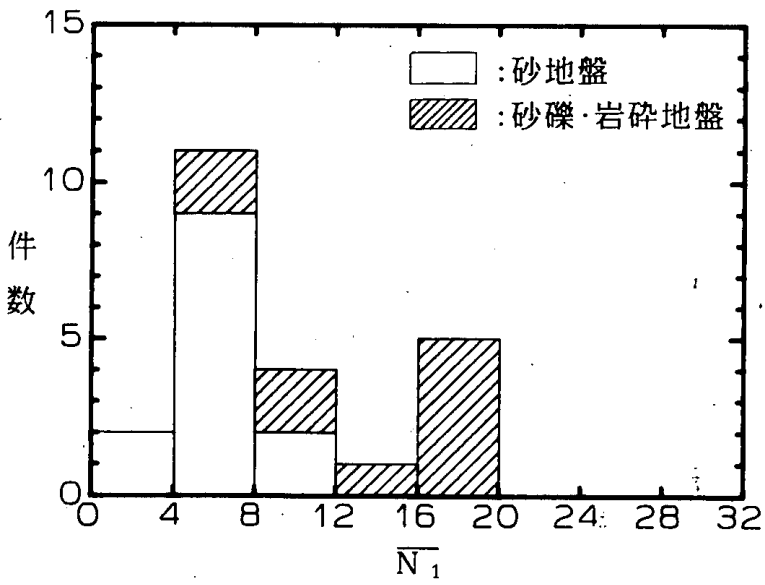

図一 $5 \bar{N}_{1}$ のヒストグラム

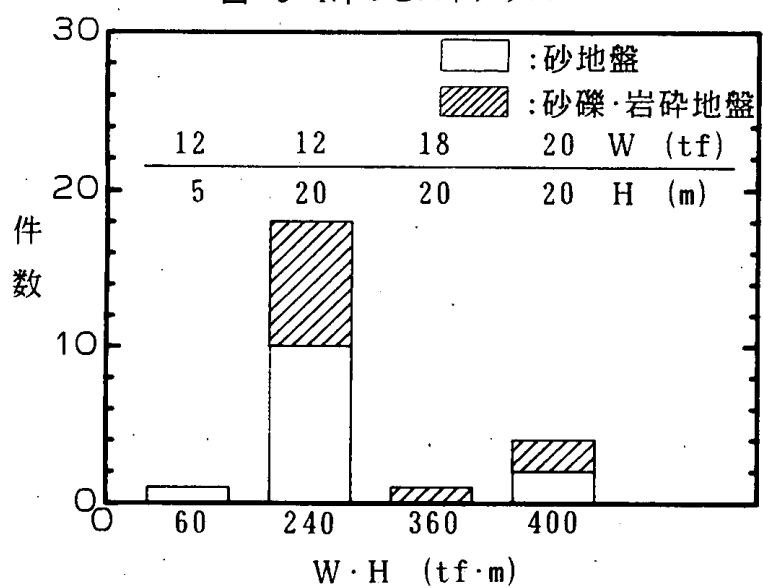

図一6 本タンピングにおける $W \cdot H$ のヒストグラム

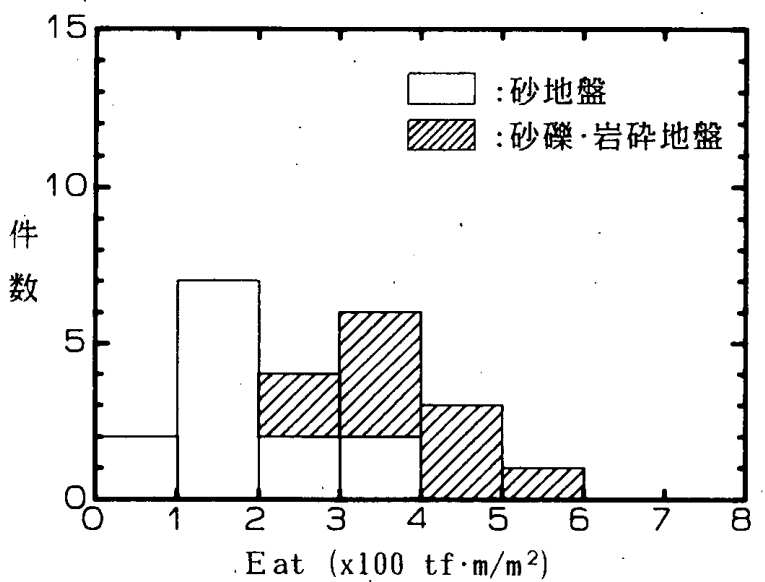

図一7 $E_{a t}$ のヒストグラム

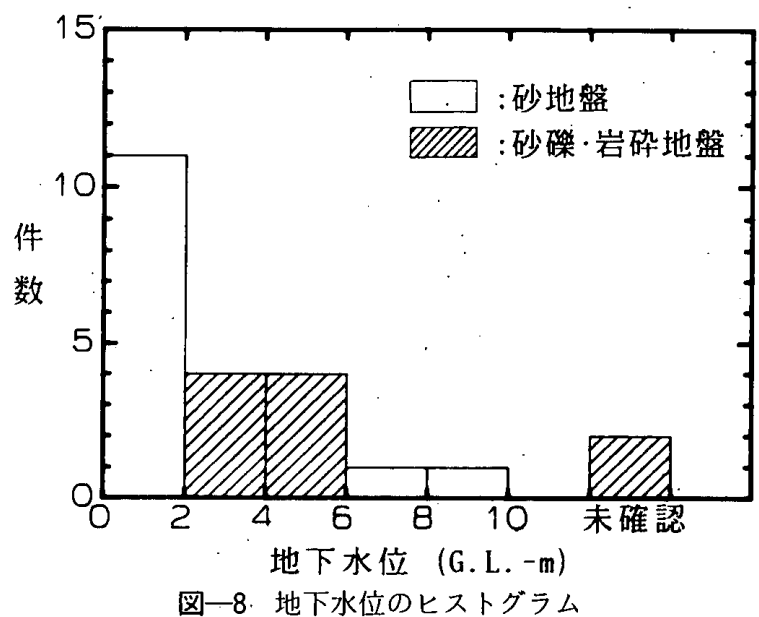

高さ $H, 1$ 打撃点の打撃回数 $n$, 打撃点間隔 $l$ ) が明示 されていること。

3）施工前後において $N$ 值が測定されていること。 これらの条件をすべて満たす資料は計 23 件（砂地盤 13 件，砂砅・岩砕地盤 10 件）であった。ただし，同一工 事であって:も施工区域が数ブロックに分かれて調查され ているものは別件として扱ってある。なお，同じ相対密 度であっても砂碩・岩砕地盤における $N$ 值は砂地盤の 場合に比べて大きく測定されると考えられるので，以下 の検討においては, 地盤を砂地盤と砂喽・岩砕地盤とに 区別することとする。

資料の概要について以下に述べる。

1) $N_{1}$ の平均値 $\bar{N}_{1}$ のヒストグラムを図一 5 に示す。 $\bar{N}_{1}$ としては，各資料中のすべての $N_{1}$ の平均值を採用 したが, 結果として $N_{1}$ の算定深度は改良深度 $D_{N}+$ 数 $\mathrm{m}$ 程度までであった。 $\bar{N}_{1}$ は砂地盤の場合平均 5.9 , 砂 磷・岩砕地盤の場合平均 13.9 であり，全体的に砂地盤 における $\bar{N}_{1}$ は砂磷・岩砕地盤に比べて小さいことがわ かる。

2）本タンピングにおける $W \cdot H$ のヒストグラムを図 一6に示す。重鍾重量 $12 \mathrm{tf}$, 落下高さ $20 \mathrm{~m}$ の仕様が最 もよく採用されていることがわかる。重錘底面の形状は， $W=12 \mathrm{tf}$ のものは幅 $B=1.75 \mathrm{~m}$ の正方形であり, $W=$ $18 \mathrm{tf}$ のものは $B=2.0 \mathrm{~m}$ の正方形, $W=20 \mathrm{tf}$ のものは $B=2.0 \mathrm{~cm}$ の正方形が 3 件, 直径 $2.32 \mathrm{~m}$ の円形が 1 件 である。なお，施工途中で $W \cdot H$ を変更している場合 が 1 件あったため, 同図における資料の総数は 24 件と なっている。

3）仕上げタンピングにおける $W \cdot H$ のヒストグラム

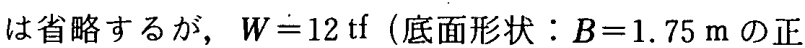
方形), $H=10 \mathrm{~m}$ の仕様が 14 件（砂地盤 6 件, 砂碩・岩 砕地盤 8 件)，W=5 tf (底面形状 : $B=1.75 \mathrm{~m}$ の正方 形), $H=10 \mathrm{~m}$ の仕様が 8 件（砂地盤 7 件, 砂砅・岩砕 地盤 1 件)，W=20 tf (底面形状：直径 $2.32 \mathrm{~m}$ の円形), $H=6 \mathrm{~m}$ の仕様が砂碟・岩砕地盤で 1 件であった。

4）本タンピングと仕上げタンピングによる単位面積あ たりの打撃エネルギーの総和 $E_{a t}((5)$ 式および（6) 式参照) のヒストグラムを図一7に示す。 $E_{a t}$ は砂地盤 の場合平均 $209.4 \mathrm{tf} \cdot \mathrm{m} / \mathrm{m}^{2}$, 砂碩・岩砕地盤の場合平均 $382.7 \mathrm{tf} \cdot \mathrm{m} / \mathrm{m}^{2}$ であり，全体的に砂地盤において採用さ れる $E_{a t}$ は砂碟・岩砕地盤に比べて小さいことがわか る。

5）地下水位のヒストグラムを図一8に示す。砂地盤の 場合，地下水位が G. L. $-2 \mathrm{~m}$ 以下のものがほとんどで あるが，これらはすべて浚渫埋め立て地盤における記録 である。なお，砂碟・岩砕地盤のうち 2 件の資料で地下 水位が確認されていないが,これらは丘陵部の盛土地盤 におけるものである。 
6）各施工段階までの単位面積当たりの打撃エネルギー の累計値 $\Sigma E_{a}$ と地表面平均沈下量の累計値 $\Sigma s$ との 関係を図一9(a) に示す。ここに, 地表面平均沈下量は, 各施工段階において地均しをした後のレベル測量から求 めたものである。全体的な傾向として, 同じ $\sum E_{a}$ に対 して, 砂地盤の $\Sigma s$ が砂碟・岩砕地盤の場合に比べて 大きいこと，また， $\Sigma E_{a}$ と $\Sigma s$ との関係は線形関係 ではなくて，次第に締固めの効率が低下する傾向にある ことがわかる。図一 $9(\mathrm{~b})$ には, $\sqrt{\sum E_{a}}$ と $\Sigma s$ との関 係を示す。バラツキはあるが, $\sqrt{\sum E_{a}}$ と $\sum s$ とは図一 9(a)に比べて線形関係にあるとみてよかろう。なお， 砂啋・岩砕地盤の資料のなかで， 2 件の資料の $\Sigma s$ が 他に比べて大きいが,これは, 非常にゆるい盛土地盤 $\left(\bar{N}_{1}\right.$ =8.7，7.5）における記録である。

これら 23 件の資料について, 中間の工事段階におい て $N$ 值が測定されているものを別件資料として扱うと, 資料は 37 件（砂地盤 18 件, 砂磉・岩砕地盤 19 件）と なる。

この 37 件の資料について， $N_{1}$ および $N_{2}$ の分布を検 討し, 改良深度 $D_{N}$ の判定を行うとともに, 改良程度の 指標として $N_{2}$ の平均値 $\bar{N}_{2}$ を算定した。なお， $\bar{N}_{2}$ とし ては, $\bar{N}_{1}$ の場合と同様にすべての $N_{2}$ の平均値を採用
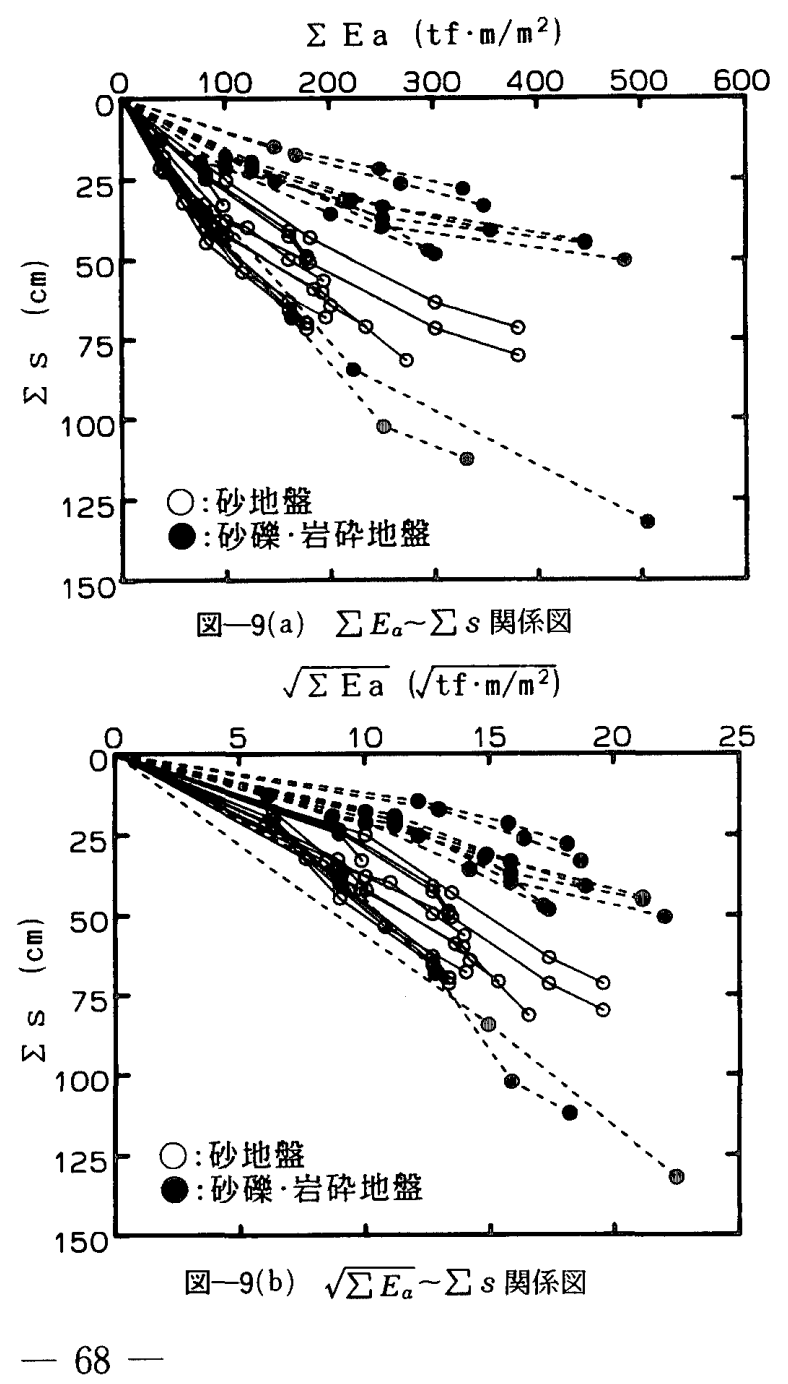

した。また， $D_{N}$ の判定において， $N$ 值の近似曲線が交 差しない場合は, 最深の $N$ 值測定樑度までの範囲で 2 曲線の水平距離（平均的な $N$ 值の増分）が最小となる 深度を $D_{N}$ として採用した。2 曲線だ交差しなかった資 料は 6 件（砂地盤 4 件，砂磻・岩砕地盤 2 件）ですった。

(1) 式による算定 $N$ 值に対する実測 $N$ 値の比の標 準偏差をヒストグラムにして図一10に示す。それぞれ の平均值は, 砂地盤の場合施工前 0.42 , 施工後 0.38 , 砂砂・岩砕地盤の場合施工前 0.29 , 施工後 0.25 であり, 砂地盤では多少精度が悪いが, $N$ 值の深度分布は (1)

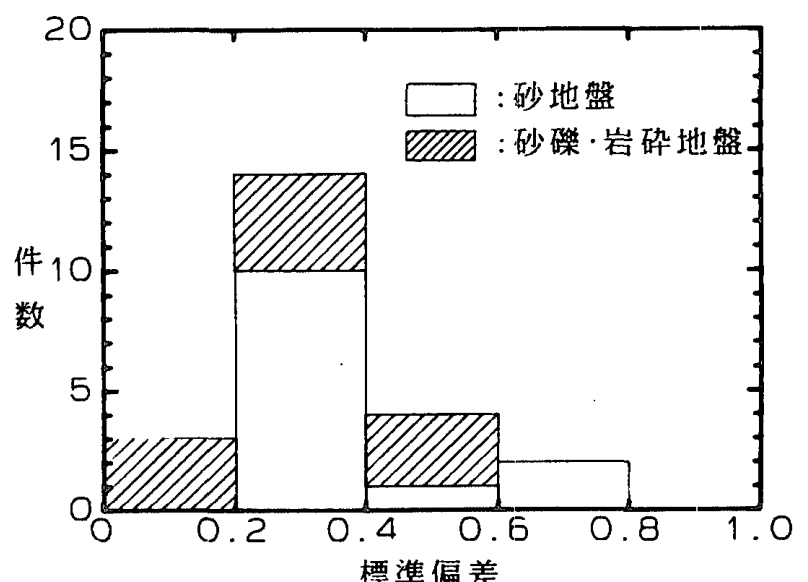

図一10(a) 標準偏差のヒストグラム（施工前）

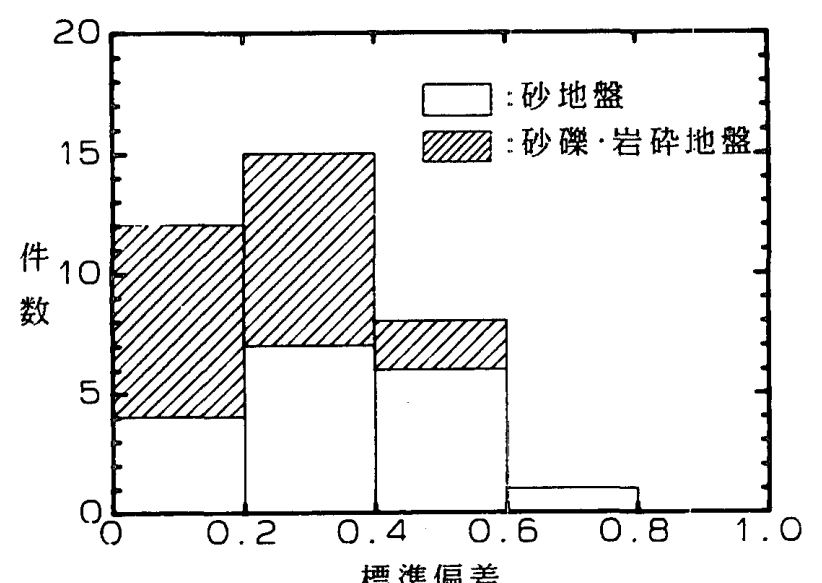

標準偏差

図一10(b) 標準偏差のヒストグラム（施工後）

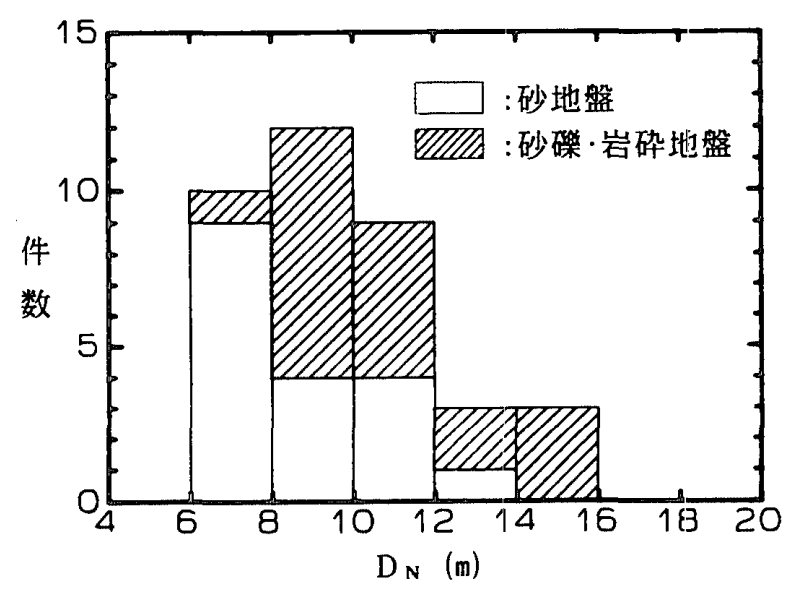

图一11 $D_{N}$ のヒストグラム 
式でほぼ近似できるものと考える。

$D_{N}$ のヒストグラムを図一 11 に示す。 $D_{N}$ は砂地盤の 場合平均 $8.6 \mathrm{~m}$, 砂碩・岩砕地盤の場合平均 $10.7 \mathrm{~m}$ で あり，全体的に砂地盤における $D_{N}$ は砂磁・岩砕地盤に 比べて小さいことがわかる。また，図一 12 には， $D_{N} / B$

$(B$ ：重鍾底面の幅，円形の場合は直径）のヒストグラ 厶を示す。なお，Bは本タンピングにおいて使用した 重錘の值を採用している。 $D_{N} / B$ は砂地盤の場合平均 4.7 , 砂碩・岩砕地盤の場合平均 5.9 である。

図一13には， $\bar{N}_{2}$ のヒストグラムを示す。 $\bar{N}_{2}$ は砂地 盤の場合平均 10.9 , 砂磷・岩砕地盤の場合平均 21.3 で あり，先述の $\bar{N}_{1}$ と同様，全体的に砂地盤における $\bar{N}_{2}$ は砂砅・岩砕地盤に比べて小さいことがわかる。

図一14には，全資料における增加 $N$ 值 $\Delta N$ （図一 4 中の 2 曲線の差) を $\bar{N}_{2}$ で除したものの深度分布曲線を 示す。ただし，深度 $z$ は $D_{N}$ で除してある。曲線形状に はかなりのバラツキが見られるが，N 值測定点と本夕 ンピングの平面位置の関係，仕上げタンピングの程度な ビによるものと考えられる。したがって，同図中の太線 で示した平均値で大局的な傾向を考察すると，砂地盤で は浅部ほど改良効果が現れているのに対し，砂碟・岩砕 地盤では $0.6 D_{N}$ あたりで最も改良効果が現れているこ

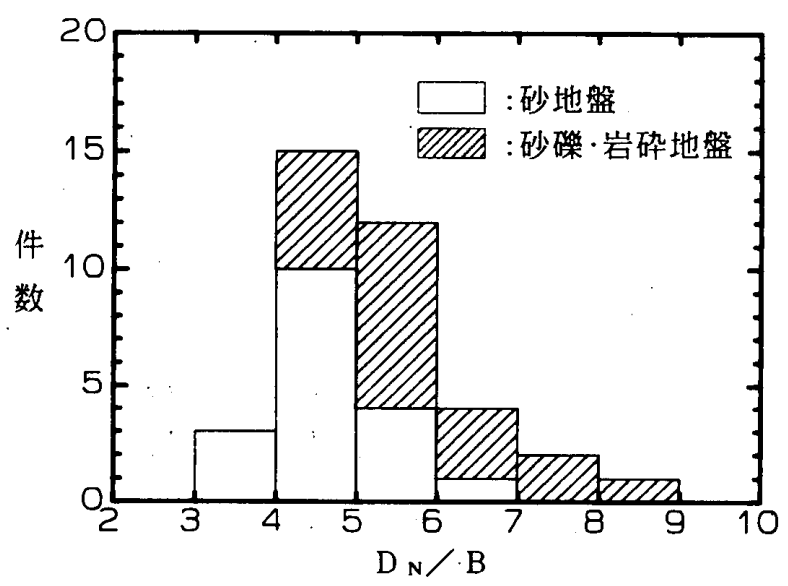

图一12 $D_{N} / B$ のヒストグラム

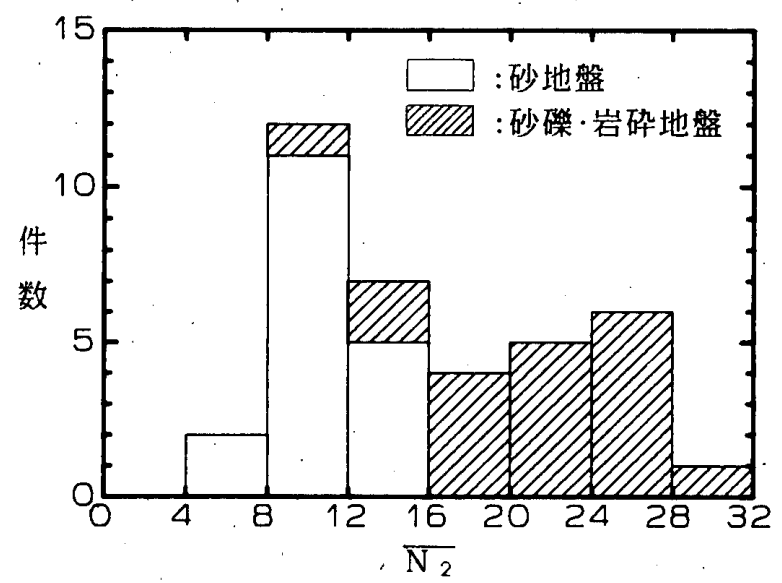

図一13 $\bar{N}_{2}$ のヒストグラム
とがわかる。これらの平均値の式は，以下のとおりであ る。

砂地盤

$$
\frac{\Delta N}{\bar{N}_{2}}=0.68+0.47 \frac{\dot{z}}{D_{N}}-1.10\left(\frac{z}{D_{N}}\right)^{2} .
$$

砂碟・岩砕地盤

$$
\frac{\Delta N}{\bar{N}_{2}}=-0.27+2.83 \frac{z}{D_{N}}-2.54\left(\frac{z}{D_{N}}\right)^{2}
$$

$$
\triangle \mathrm{N} / \overline{\mathrm{N}_{2}}
$$

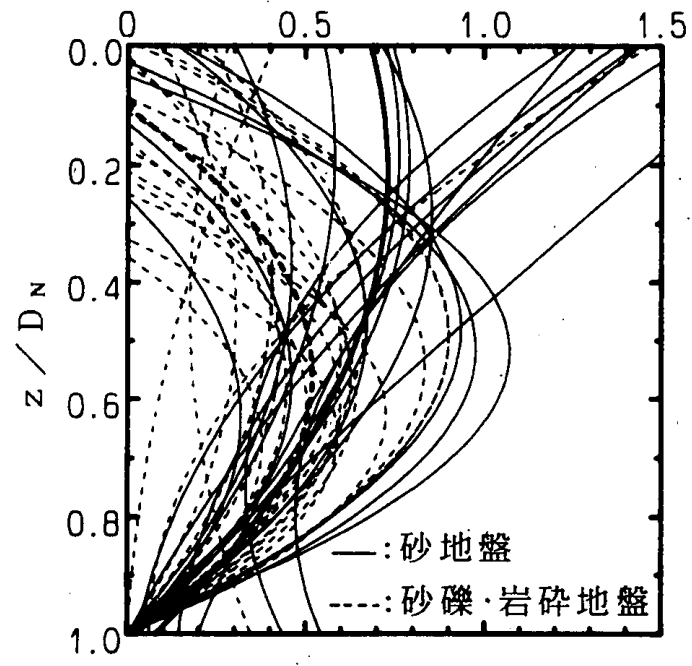

图一14 $\Delta N / \bar{N}_{2} \sim z / D_{N}$ 関係図

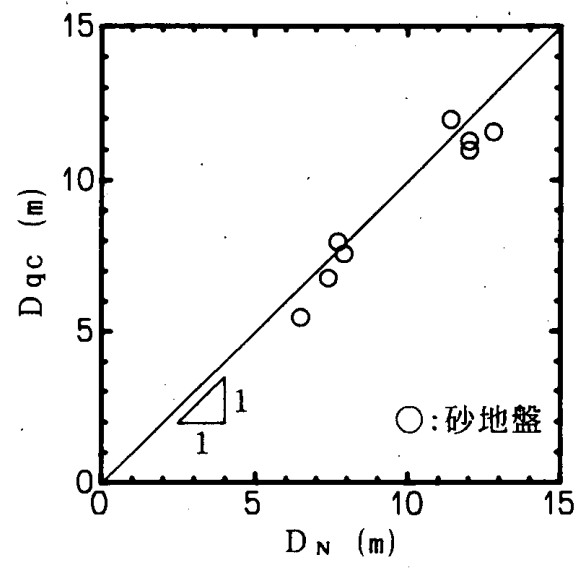

図一15(a) $\quad D_{q c} \sim D_{N}$ 関係図

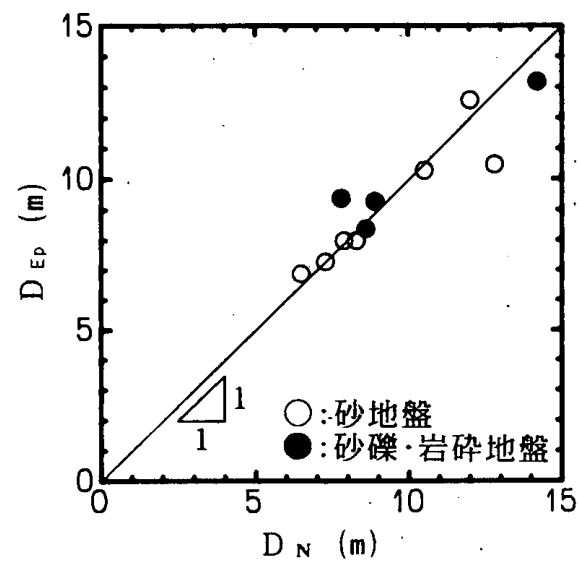

图一15(b)， $D_{E_{p}} \sim D_{N}$ 関係図 
資料のうち，標準貫入試験以外にコーン貫入試験ある いは孔内水平載荷試験が実施されているものについて は, 先述の $D_{N}$ と同様, コーン貫入抵抗 $q_{c}$ あるいは変 形係数 $E_{p}$ の深度分布の近似曲線から改良深度 $D_{q_{c}}$ ある いは $D_{E_{p}}$ を判定した。図一15には， $D_{q_{c}}$ および $D_{E_{p}}$ と $D_{N}$ との関係を示す。多少のバラツキは認められるが, $D_{q_{c}}$ および $D_{E_{p}} も D_{N}$ と同等とみてよかろう。

\section{4. 改良深度および改良程度の推定式}

2. で述べた現行設計法の問題点をふまえたうえで，打 撃点間隔および打撃エネルギーの総量を反映しうる単位 面積当たりの打撃エネルギーの累計值 $\sum E_{a}$ と施工前の 相対密度を表す $\bar{N}_{1}$ に着目し， $D_{N}$ および $\bar{N}_{2}$ と両者との 関係について検討を行った。検討にあたっては, 改良効 果 $\left(D_{N}, \bar{N}_{2}\right)$ は打撃エネルギーが大きく地盤の相対密 度がゆるいほど顕著に現れると考え, 以下の形の線形重 回帰式による推定式を求めることとした。

改良効果 $\left(D_{N}, \bar{N}_{2}\right)=a+b \cdot$ (打擊エネルギ一)

$$
-c \cdot(\text { 相対密度 })
$$

なお, 本タンピングと仕上げタンピングの各 $E_{a}$ は（ 5 ) および（6）式であって， $\sum E_{a}$ は対象とする施工段階 までの $E_{a}$ の累計値とする。

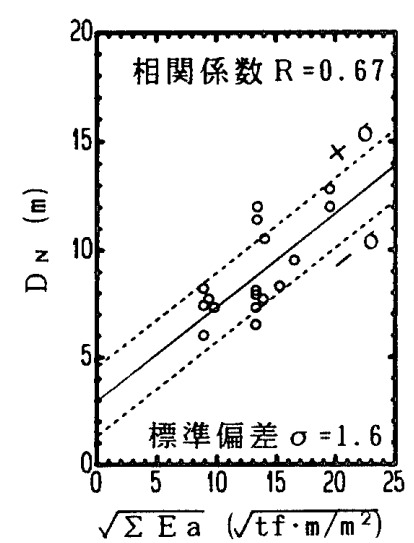

(a) 砂地盤

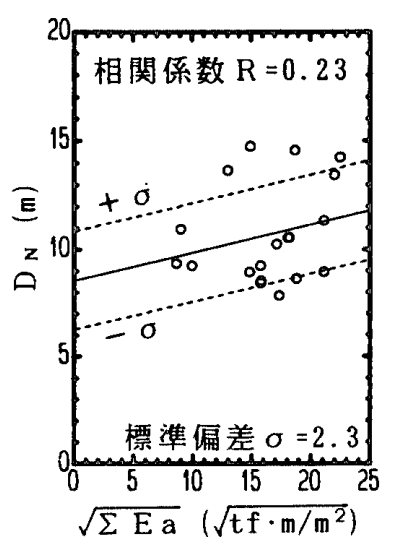

(b) 砂磷·岩砕地盤

$$
\text { 図一16 } D_{N} \sim \sqrt{\sum E_{a}} \text { 関係図 }
$$

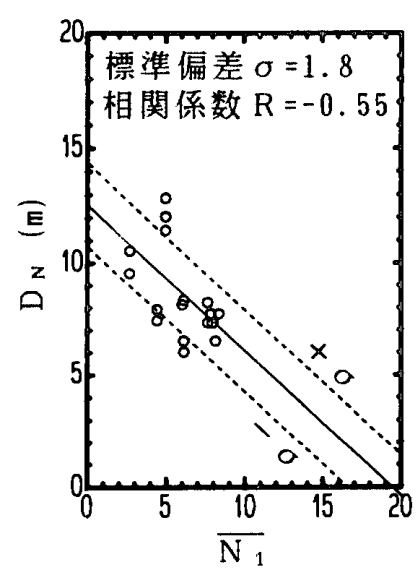

（a）砂地盤

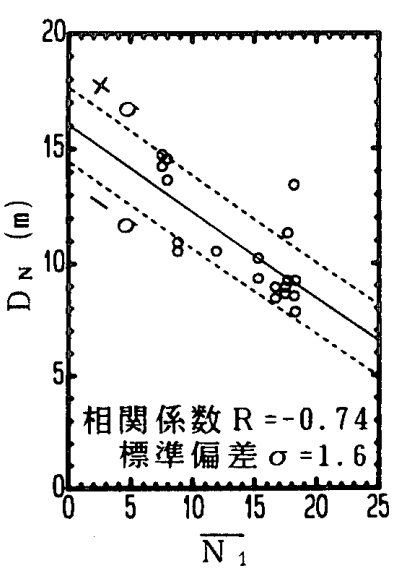

（b）砂砂·岩砕地盤
図一17 $\quad D_{N} \sim \bar{N}_{1}$ 関係図
本夕ンピング $\quad E_{a}=n \cdot W \cdot H / l^{2}$

仕上げタンピング $E_{a}=n_{s} \cdot W \cdot H / A \cdots$

ここに

\section{$n:$ 本タンピング打撃回数 \\ $W$ : 重鍾重量 $(\mathrm{tf})$}

$H$ : 重鍾落下高さ $(\mathrm{m})$

$l$ : 打撃点間隔 $(\mathrm{m})$ (図一 -1 参照)

$n_{s}$ : 仕上げタンピング総打撃回数

$A$ ：仕上げタンピング施工面積 $\left(\mathrm{m}^{2}\right)$ (図一1 参照)

図一16 および図一17には，改良深度 $D_{N}$ と $\sqrt{\sum E_{a}}$ お よび $\bar{N}_{1}$ との関係を示す。ここで， $\sum E_{a}$ の平方根を採 用したのは，打撃エネルギーの締固めに対する効率を， 従来の評価（図一2）および図一 9 (b) の傾向を考虑し て $1 / 2$ 乗と想定したことによる。砂䃋・岩砕地盤の場合, 砂地盤と比べてバラツキが大きいようであるが，大局的 にみて $D_{N}$ は $\sqrt{\sum E_{a}}$ および $\bar{N}_{1}$ に対して線形關係にあ るとみなしてよかろう。したがって， $\sqrt{\sum E_{a}}$ および $\bar{N}_{1}$ を $D_{N}$ の説明変数として線形重回州式を以下の上うに求 めた。

砂地盤

$$
D_{N}=6.3+0.35 \sqrt{\sum E_{a}}-0.37 \bar{N}_{1}
$$

砂碩・岩砕地盤

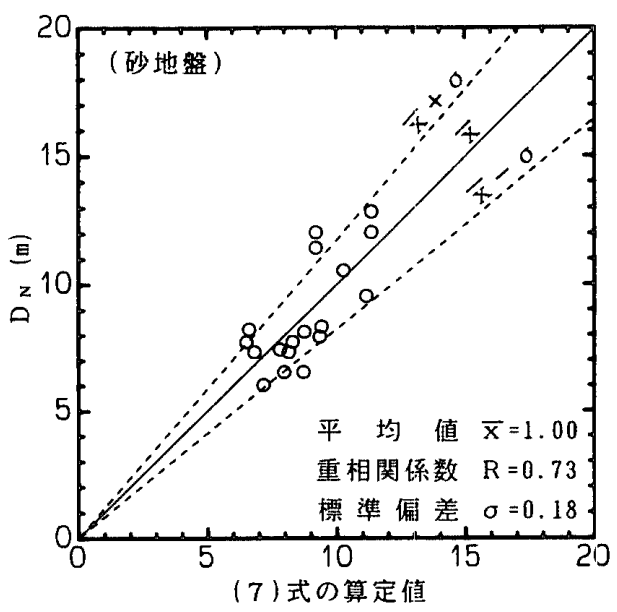

図一18(a) $D_{N}$ と（7）式の算定値との相関図

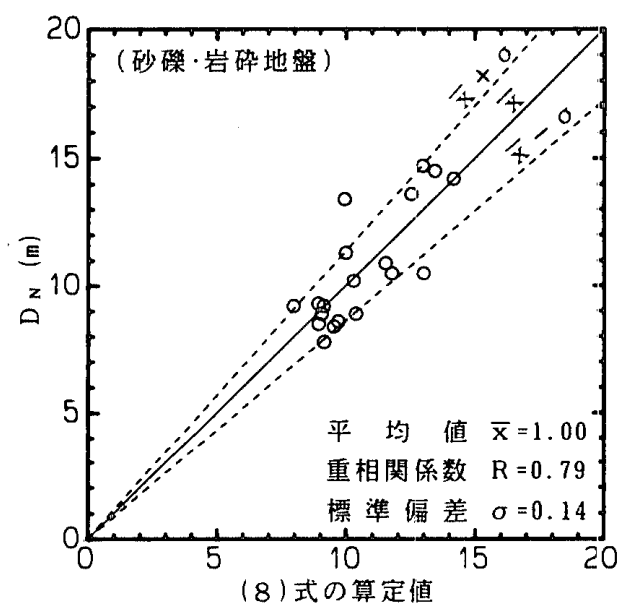

図一18(b) $D_{N}$ と（8）式の算定値との相関図 


$$
D_{N}=13.5+0.16 \sqrt{\sum E_{a}}-0.39 \bar{N}_{1}
$$

ただし， $D_{N}$ の単位は $\mathrm{m} て ゙ あ り ， E_{a}$ の単位は $\mathrm{t} \cdot \mathrm{m} / \mathrm{m}^{2}$ である。 $D_{N}$ と（7) 式および（8）式による算定值と の相関図を図一18に示したが，重相関係数などから判 断して，（7）式および（8）式は検討対象資料の傾向 をよく近似していると考える。また，参考のため， $D_{N} / B$ についても $D_{N}$ の場合と同様に以下の線形重回帰 式を求めた。

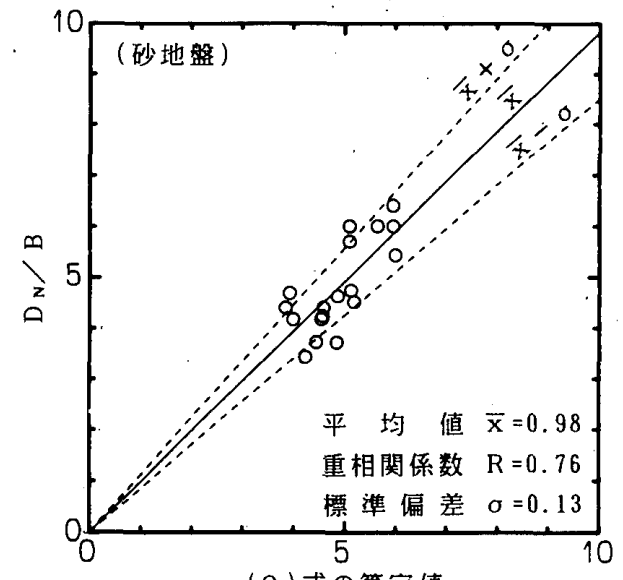

(9)式の算定値

困一19(a) $D_{N} / B$ と（9) 式の算定值との相関図

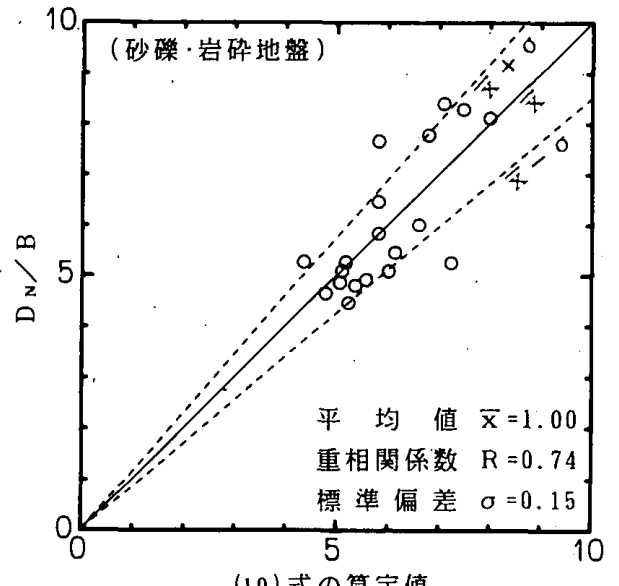

(10)式の算定値

困一19(b) $D_{N} / B$ と（10）式の算定値との相関図
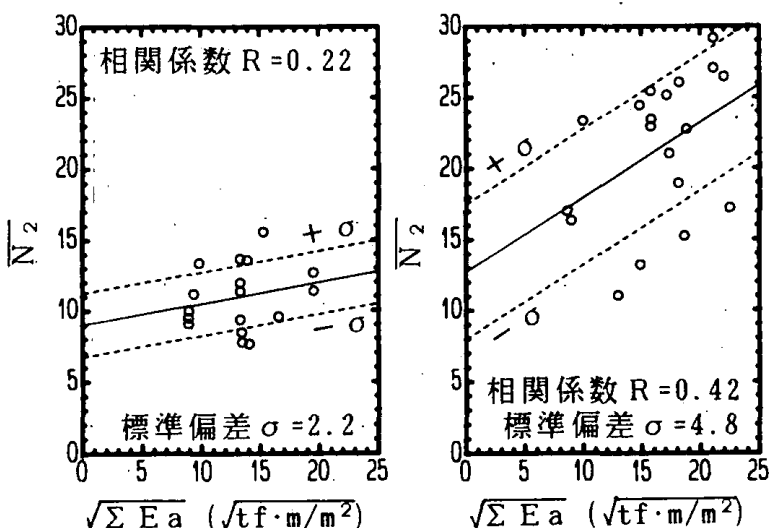

(a) 砂地盤

(b) 砂碟·岩砕地盤

図一20 $\bar{N}_{2} \sim \sqrt{\sum E_{a}}$ 関係図
砂地盤

$$
D_{N} / B=4.2+0.14 \sqrt{\sum E_{a}}-0.20 \bar{N}_{1}
$$

砂砅・岩砕地盤

$$
D_{N} / B=6.8+0.12 \sqrt{\sum E_{a}}-0.20 \bar{N}_{1}
$$

$D_{N} / B$ と（9）式および（10）式による算定値との相関 図を図一19 に示す。B の範囲が $1.75 \mathrm{~m} \sim 2.32 \mathrm{~m}$ と限ら れているが，今後異なる底面形状の重錘を使用する際の 参考になると考える。

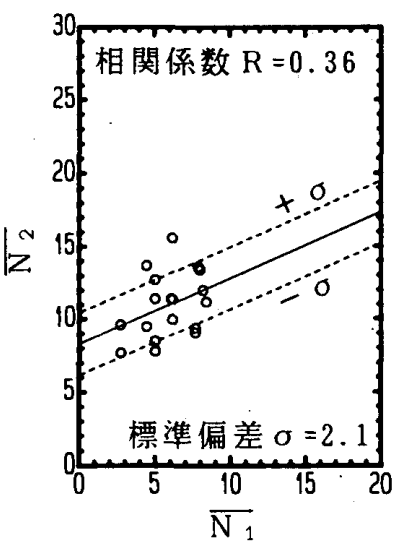

(a) 砂地盤

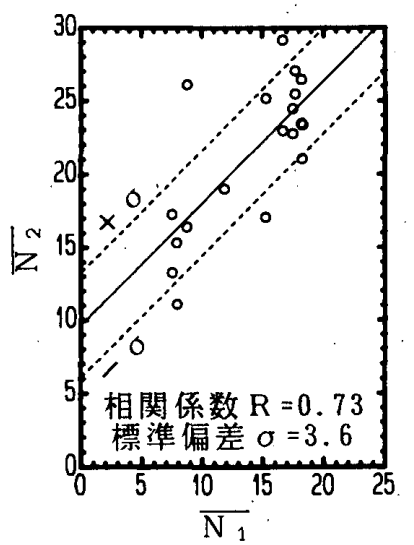

(b) 砂磷·岩砕地盤
図一21 $\bar{N}_{2} \sim \bar{N}_{1}$ 関係図

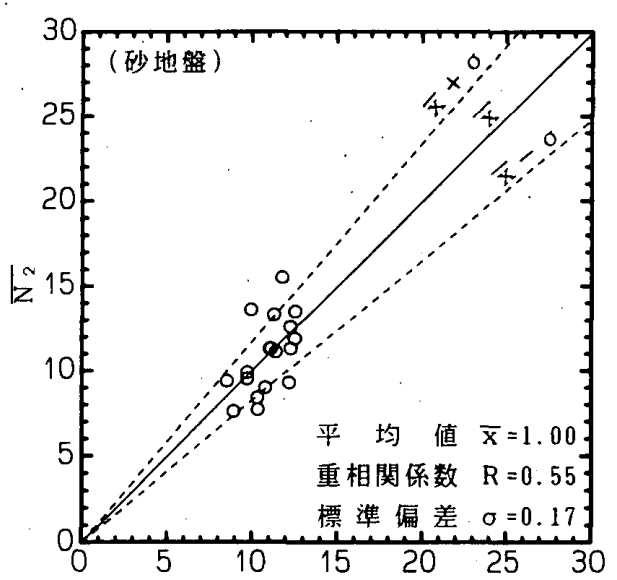

(11)式の算定值

図-22(a) $\bar{N}_{2}$ と (11) 式の算定値との相関図

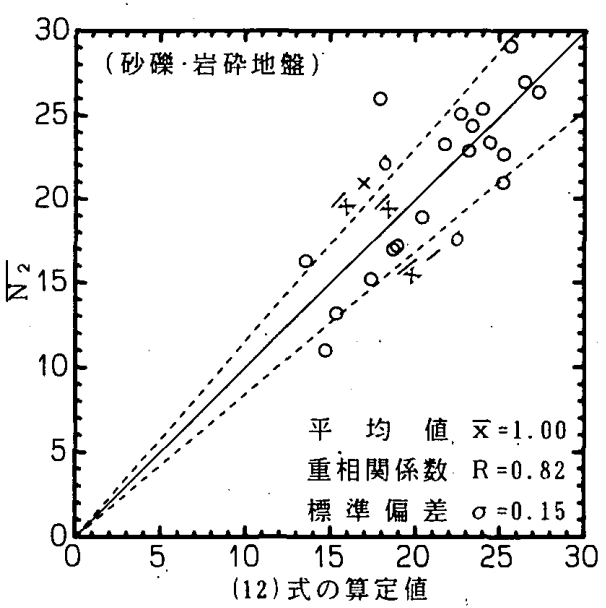

図一22(b) $\bar{N}_{2}$ と（12）式の算定値との相関図 
表一1 検討工事の概要

\begin{tabular}{|c|c|c|c|}
\hline & 文献 ${ }^{111}$ & 文献 ${ }^{121}$ \\
\hline \multicolumn{2}{|c|}{ 地盤種別 } & 砂地盤 & 岩砕地盤 \\
\hline \multicolumn{2}{|c|}{ 重鍾重量W (tf) } & \multicolumn{2}{|c|}{20} \\
\hline \multicolumn{2}{|c|}{ 落下高さH $\quad(\mathrm{m})$} & \multicolumn{2}{|c|}{25} \\
\hline \multicolumn{2}{|c|}{ 打撃回数 n （回) } & 35 & 15 \\
\hline \multicolumn{2}{|c|}{ 打擊点間隔 $\ell$ (m) } & 9 & 5 \\
\hline \multicolumn{2}{|c|}{ 施工段階 } & 2 & 1 \\
\hline \multicolumn{2}{|c|}{ 仕上げタンピング } & 無 & 有 \\
\hline \multicolumn{2}{|c|}{$\overline{\mathrm{N}_{1}}$} & 9.8 & 10.6 \\
\hline \multicolumn{2}{|c|}{$\left(t f \cdot m / m^{2}\right)$} & 432 & 380 \\
\hline \multirow{2}{*}{$D_{N}(m)$} & 実測値 & 10.1 & 13.1 \\
\hline & 推定値 & 9.9 & 12.5 \\
\hline \multirow{2}{*}{$\overline{\mathrm{N}_{2}}$} & 実測値 & 18.5 & 16.7 \\
\hline & 推定値 & 16.1 & 20.0 \\
\hline
\end{tabular}

図一20および図一21図には, $\bar{N}_{2}$ と $\sqrt{\sum E_{a}}$ おび $\bar{N}_{1}$ との関係を示す。 $D_{N}$ の場合と同様に, 線形関係を想定 してょいものと判断し， $\sqrt{\Sigma E_{a}}$ および $\bar{N}_{1} を \bar{N}_{2}$ の説明 変数として線形重回帰式を以下のように求めた。

砂地盤

$$
\bar{N}_{2}=2.6+0.32 \sqrt{\sum E_{a}}+0.70 \bar{N}_{1}
$$

砂碩・岩砕地盤

$$
\bar{N}_{2}=2.3+0.47 \sqrt{\sum E_{a}}+0.81 \bar{N}_{1}
$$

ただし， $E_{a}$ の単位は $\mathrm{tf} \cdot \mathrm{m} / \mathrm{m}^{2}$ である。 $\bar{N}_{2}$ と (11) 式お よび（12）式による算定值との相関図を図一22 に示す。 砂地盤の場合 $\bar{N}_{2}$ の範囲が狭いこともあって重相関係数 が多少小さいが，(11）式および（12）式は検討対象資 料の傾向をよく近似していると考える。

\section{5. 最近の施工事例との比較}

4.で提案した改良深度および改良程度の推定式の妥当 性を検討するため, 最近公表された 2 例の施工結果 ${ }^{11), 12)}$ についてこれらの推定式を適用してみることとした。ち なみに，上述の提案式を求めるために使用した資料は， 1988 年以前の資料であって，この 2 例は含まれていな い。

地盤概要および打撃仕様をまとめて表一 1 に示す。表 -1 中には，（7)，（8）式および（11）（12）式の推

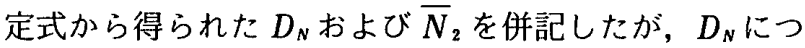
いては，実測值と推定値はよく一致している。一方， $\bar{N}_{2}$ については若干の差が認められるが，この程度の相 違はやむをえないと考える。また，図一23には，施工 前後の実測 $N$ 值の近似曲線とともに， $D_{N}$ および $\bar{N}_{2}$ の 上記推定値を（2)，（3）式に代入して求めた施工後の $N_{2}$ 值 $\left(N_{1}\right.$ 曲線 $\left.+\Delta N\right)$ の深度分布 (推定 $N_{2}$ 近似曲線) を併記した。砂地盤（図一23(a)）の場合は，浅部にお いて推定値が実測值より大きな值を示しているが，これ は，仕上げタンピングが行われていないためと考えられ
$\mathrm{N}$ 值
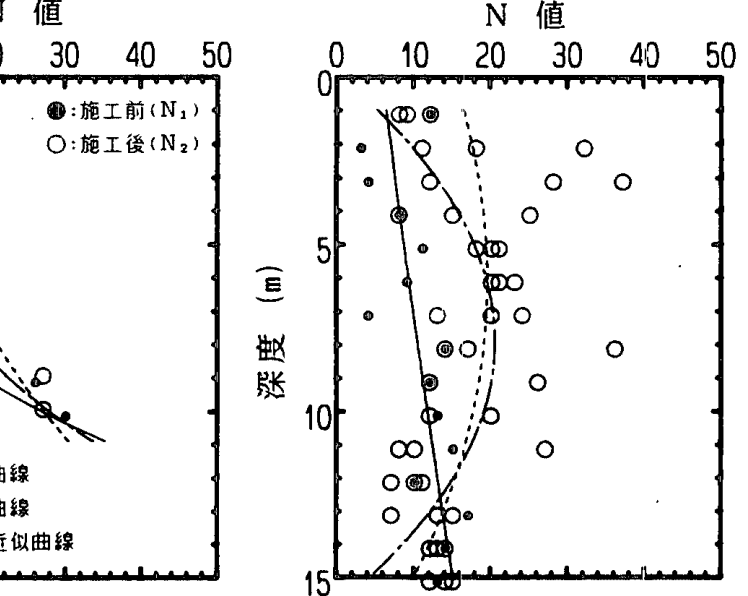

(b) 岩砕地盤121

(a) 砂地盤 ${ }^{11}$ )

図一23 検討工事における $N$ 値の深度分布図

る。また岩砕地盤（図一23(b)）の場合は，浅部におい て推定值が実測値より小さな值を示した。これは，浅部 において締固められた岩砕の影響で一部の $N_{2}$ 值が過大 に測定されたためではないかと推察される。(2)，(3) 式自体が大まかな平均值であるが, 結果として, 推定 $\mathrm{N}_{2}$ 值の深度分布は，実測 $N$ 值の深度分布に比較的近似 していることがわかる。以上から，(7)，(8) 式およ び (11)，(12）式の推定式は，ほぼ妥当であると考えて よかろう。

\section{6. 結 語}

以上，砂質系地盤における重鍾落下楴固め工法の現行 設計法の問題点をふまえたうえで，過去の施工記録に基 づいて改良深度および改良程度に関する調査検討を行っ た。これらの結果をまとめると，以下のとおりである。 （1）改良深度を施工前後の $N$ 值の深度分布の近似 2 次曲線が交差する梁度 $D_{N}$ と定義した。打撃エネルギー の累計值 $\Sigma E_{a}$ および地盤の施工前の相対密度（指標： $\bar{N}_{1}$ ) を考慮して, 改良深度 $D_{N}$ の推定式として以下の線 形重回帰式を提案した。

$$
\text { 砂地盤 } \quad D_{N}=6.3+0.35 \sqrt{\sum E_{a}}-0.37 \bar{N}_{1}
$$

砂磁・岩砕地盤 $D_{N}=13.5+0.16 \sqrt{\sum E_{a}}-0.39 \bar{N}_{1}$ （2）改良程度の指標として, 施工後の平均 $N$ 值 $\bar{N}_{2}$ を考え, $\bar{N}_{2}$ の推定式として以下の線形重回帰式を提案 した。

$$
\begin{array}{ll}
\text { 砂地盤 } & \bar{N}_{2}=2.6+0.32 \sqrt{\sum E_{a}}+0.70 \bar{N}_{1} \\
\text { 砂碟・岩砕地盤 } & \bar{N}_{2}=2.3+0.47 \sqrt{\sum E_{a}}+0.81 \bar{N}_{1}
\end{array}
$$

（3）提案した $D_{N}$ および $\bar{N}_{2}$ の推定式を, 最近報告さ れた 2 例の工事結果に適用してみた。結果として， $D_{N}$ はかなりの精度で推定できた。 $\bar{N}_{2}$ に関しては若干の相 違が認められたが，現段階ではやむをえない推定誤差と 考えられた。また，検討対象資料の $\bar{N}_{2}$ の梁度分布の平 均值の式 ((2),（3）式）を適用したところ, 実測値 
に比較的近似することがわかった。

なお，本研究では，現時点で可能な限りの工事記録を 収集したが，統計的に扱うには十分な資料数とはいえな いかもしれない。今後，施工実績の積み重ねに伴って， 本報告における推定式の精度も向上させていく必要があ ると考えている。

\section{謝 辞}

本研究は，筆者らが日本国土開発株式会社からの依託 研究として夷施したものである。同社の関係各位に，感 謝致します。

\section{参考文献}

1）軟弱地盤対策工法編集委員会：軟弱地盤対策工法一調 查・設計から施工まで一, 土質工学会, pp. $321 \sim 328$, 昭和 63 年 11 月

2) 山田正俊：動任密工法, 土と基礎, 土質工学会, Vol.29, No. 5 , pp. $21 \sim 28,1981.5$

3）高田直俊, 竹内 功, 三笠正人, 池田通陽 : 重鍾落下楴 固め工法の遠心模型実験（第 1 報），土木学会第 42 回年 次学術講演会 III, pp. 16 17, 昭和 62 年 9 月

4) 大島昭彦, 高田直俊, 藤田哲治, 小谷泰範, 池田通陽 : 重錘落下楴固工法の遠心模型実験（第 2 報）, 第 23 回 土質工学研究発表会, pp. 2049 2052, 昭和 63 年 6 月

5）池田通陽, 高田直俊, 大島昭彦, 藤田哲治：重鍾落下締
固め工法の遠心模型実験 (第 3 報), 土木学会第 43 回年 次学術講演会 III, pp. 20 21, 昭和 63 年 10 月

6）大島昭彦, 高田直俊, 池田通陽：重鍾落下締固め工法の 遠心模型実験（第 4 報）, 第 24 回土質工学研究発表会, pp. $1847 \sim 1850$, 平成元年 6 月

7）大島昭彦, 高田直俊, 山本和哉：重鍾落下楴固め工法に おける打媻仕様と効果, 第 25 回土質工学研究発表会, pp. 1853 1856, 平成 2 年 6 月

8）下平祐司, 山肩邦男, 森 国夫：重鍾落下締固め工法に おける改良深度および改良程度について, 日本建築学会 大会 (九州) 学術講演梗概集<構造系>, pp. 1443 1444, 1989 年 10 月

9) Gibbs, H. J. and Holtz, W. G. : Research on Determining the Density of Sands by Spoon Penetration Testing, Proc. 4 th ICSMFE, Vol:1, pp. 35 39, 1957.8

10）下平祐司, 山肩邦男, 伊藤淳志, 南坂貴彦: 砂地盤にお ける標準貫入試験の結果に関する考察, 第 21 回土質工学 研究発表会, pp. $27 \sim 30$, 昭和 61 年 6 月

11）田中 享, 佐々木千好：4. 東北地方における代表的工事 の概要, 能代火力発電所砂地盤の液状化対策工事, 土と 基礎, 土質工学会, Vol. 37, No. 3, pp. 86 90, 1989.3

12）岩谷文方, 遠藤 博, 小松 明, 山懸延文: 関西国際空 港における埋立土の地盤改良, 第 25 回土質工学研究発表 会, pp. 1861 1864, 平成 2 年 6 . 月

(1991 年 8 月 21 日原稿受理, 1992 年 4 月 27 日採用决定) 